\title{
Timūr's theatrical journey: Or, when did Tamburlaine become black?
}

\author{
ล \\ El viaje teatral de Timūr, o
¿Cuándo se volvió negro Tamburlaine?
}

\author{
Linda McJannet \\ Bentley University, United States
}

\begin{abstract}
Reviews of modern productions of Marlowe's Tamburlaine often note a three-hundred-year hiatus between a recorded performance in 1641, just before the closing of the theatres, and Tyrone Guthrie's revival at the Old Vic in 1951. While the statement is mostly true with respect to Marlowe's play, Tamerlane or Timūr Lenk and the Ottoman emperor Bayazid I (Marlowe's Bajazeth) had important theatrical incarnations in the $1700 \mathrm{~s}$ before they declined into parody in the 1800 s. When Marlowe's play was revived in the modern era, the main characters reclaimed their dignity, but they also acquired markers of racial, ethnic, or religious otherness that had not been prominent earlier. Timūr's (and Bayazid's) varied theatrical representations illustrate the malleability of iconic cultural figures, the sometimes problematic emphasis on ethnic difference in modern theatrical practice, and the challenges and opportunities of cross-racial casting.
\end{abstract}

KEYWORDS: Christopher Marlowe, dramatic productions; stage history of Tamburlaine, parts I and II; Nicholas Rowe's Tamerlane, A Tragedy; George Frideric Handel's Tamerlano; Timūr Lenk; Bayazid I; race; colorblind casting; performing arts.

\section{RESUMEN}

Las reseñas de las producciones modernas del Tamburlaine de Marlowe a menudo dan cuenta del paréntesis de trescientos años que existió entre una representación de la obra de la que se tiene noticia en 1641, justo antes del cierre de los teatros, y su recuperación a manos de Tyrone Guthrie en el Old Vic en 1951. Aunque esta afirmación es fundamentalmente cierta en lo tocante a la obra de Marlowe, Tamerlane o Timūr Lenk, junto con el emperador otomano Bayazid I (el Bajazeth de Marlowe) tuvieron importantes encarnaciones en el teatro en el siglo XVIII, antes de degradarse y convertirse en parodia en el siglo XIX. Cuando la obra de Marlowe fue recuperada en la época moderna los personajes principales recobraron su dignidad, pero también adquirieron unos marcadores de alteridad racial, étnica o religiosa que no habían sido prominentes anteriormente. Las variadas representaciones teatrales de Timūr (y de Bayazid) ilustran la maleabilidad de los iconos culturales, el énfasis a veces problemático en la diferencia étnica en la práctica teatral moderna, y los retos y las oportunidades de un reparto interracial.

PALABRAS CLAVE: producciones teatrales de Christopher Marlowe; historia de las representaciones de Tamburlaine, partes I y II; Tamerlane, A Tragedy (Nicholas Rowe); Tamerlano (Georg Frideric Handel); Timūr Lenk (Tamerlane) en la literatura; Bayazid I en la literatura; raza en la literatura; reparto sin distinción de color; artes escénicas.

\section{Prologue}

Stage histories of Christopher Marlowe's Tamburlaine often begin by noting the three-hundred-year hiatus between a recorded performance in 1641 and Tyrone Guthrie's revival of the play in 
1951. ${ }^{1}$ The claim is mostly true with respect to Marlowe's play, but the originals of Marlowe's main characters, the Central Asian conqueror Timūr Lenk (or Tamerlane) and his main antagonist, the Ottoman sultan Bayazid I, had other theatrical incarnations in Europe during those years. An awareness of these incarnations of Timūr and Bayazid enriches our understanding of Marlowe's place in an arc that links the historical figures with their early modern stage counterparts, their modern real-life appropriators, and their recent theatrical incarnations. According to historian Adam Knobler, Timūr's career exemplifies the "portability of the past" (2006, 293); at times, it was an "empty slate upon which Orientalist fantasies and practical foreign and domestic politics could be written and discussed without risk of offending contemporary sensibilities" (2001, 111-12). However, theatrical appropriations of Timūr are not limited to the East-West binary articulated by Edward Said in Orientalism (1978). They remind us that charismatic historical figures and their avatars are global cultural commodities around which communities unpredictably form.

This essay traces Timūr's theatrical journey with an emphasis on the oscillation between "bloodthirsty barbarian" and "ideal ruler" and the markers (if any) of race, religion, and class that distinguished him from his rivals and/or from the audience expected for a particular work. ${ }^{2}$ While Timūr and Bayazid were larger than life and sometimes demonized in the sixteenth and early seventeenth centuries, they were domesticated during the Restoration and eighteenth century, only to be re-vilified and reduced to parody in the nineteenth. ${ }^{3}$ When Marlowe's play returned to the stage in the twentieth century, however, they regained their dignity and power, and in recent decades they began to be played by actors of African ancestry. Timūr's and Bayazid's

\footnotetext{
${ }^{1}$ See, for example, Dawson (1997, xxix).

${ }^{2}$ In referring to the historical characters, I will use the names most historians use, Timūr and Bayazid. For dramatic incarnations other than Marlowe's, I will use the names given in those works, usually "Tamerlane" and "Bajazet." In speaking of Marlowe's characters, I will use his spelling, "Tamburlaine" and "Bajazeth."

${ }^{3}$ Knobler reports that seven comic plays and parodies "of the most unsophisticated variety" were performed or published between 1800 and 1850 , including Timour the Cream of Tartar (1845) by Gilbert à Beckett, founder of Punch magazine (2001, 110-111).
} 
roots were in Anatolia and Central Asia, not Africa. ${ }^{4}$ However, I am interested not in the historical accuracy of their representations, but in when and how these characters were represented as racially, ethnically, and/or religiously distinct from each other and from their putative audiences. In addition, since, to my knowledge, an actor of Asian descent has never played Tamburlaine in the West, what kind of triangulation is occurring if, after years of imagining him as European, actors with African roots are the first actors of color to fill the lead roles?

\section{Timūr the Charismatic Barbarian}

Historian Beatrice Manz, has argued that:

Despite changes in state legitimation, society, and culture in the centuries since Temür lived, the ideal of the powerful ruler, ruthless and charismatic, seems to have remained disconcertingly constant. The image of a man of will and destiny rising from low station to rule the world [...] appealed to the writers of the European Renaissance, to wartime Soviet writers and now to the rulers of independent Uzbekistan. (Manz 2002, 25)

Nonetheless, the emphasis in Western representations of the conqueror has varied, sometimes stressing his bloody ruthlessness and sometimes his charisma and military success. Some medieval European writers saw him positively, as a savior from the "terrible Turks" (Knobler 2001, 101). Stephen Greenblatt (1980), Daniel Vitkus (2001), and Richmond Barbour (2003) have argued that Timūr's aspiring mind and interest in global commerce appealed to the New

\footnotetext{
${ }^{4}$ Evidence for the physical appearance of the historical Timūr emerged when his body was exhumed in 1941. According to his biographer, Hilda H. Hookam, Timūr was lame in "both right limbs," powerfully built, and "bristles of a chestnut moustache" were still visible on his remains $(1978,425)$. Culturally, however, Timūr's appearance was determined by his representers. A sixteenth-century Persian miniature with pronounced eye-folds in the collection at Topkap1 Palace in Istanbul (see Hookham 1978 , 424) bears little resemblance to the bust with rugged features based on the reconstruction created by Russian forensic archeologist Mikhail Mikhaylovich Gerasimov in 1941 (see Historum 2012).

${ }^{5}$ After the fall of the Soviet Union, Uzbek leaders erected statues to Timūr in Samarkand and Tashkent. Although ethnic Uzbeks arrived in that part of the world long after Timūrid times, Uzbek President, Islam Karimov, identified himself with Timūr during his campaign for reelection in 1999 (McMahon 1999).
} 
Men of the Renaissance, such as the merchant adventurers who founded the Levant and East India Companies. Later, however, as British imperial interests focused on India rather than the Levant, Timūr became vilified "as 'the bloodthirsty barbarian' par excellence," enabling apologists for the Raj to compare Timūr's bloody conquest of India with their allegedly more benign rule (Knobler 2001, 101-2, 109). Manz reviews the most barbaric anecdotes about Timūr (the massacre of whole cities, the iron cage in which he imprisoned Bayazid, the chariot drawn by captive kings) and concedes that some may be Western fabrications. Others, she asserts, "originated during [Timūr's] lifetime and came from [...] sources" close to the man himself $(2006,11)$. Indeed, Indian histories list the casualties at Delhi at 50,000 souls, but Timūr's authorized history puts them at twice that number - the reverse of what one might expect. In short, Timūr was a pre-Renaissance self-fashioner for whom "shock and awe" and a reputation for cruelty were deliberate tactics.

The charismatic conqueror that Manz describes and the bloodthirsty barbarian can both be seen in Marlowe's hero. I have argued that the figure of Bajazeth, Timūr's chief rival, is not portrayed as negatively as some critics have alleged (McJannet 2006, 65-81). However, Marlowe's version of their story favors Tamburlaine: he is the center of both plays, and all the other characters, whether Persian, Arabian, Turkish, Syrian, or Hungarian, are presented as less capable and sometimes less worthy of wielding power than he is. At least in Part I, he is a barbarian with whom we are invited -indeed compelled - to identify. As Manz observed of Timūr, Tamburlaine's successes are "so spectacular that [it seemed] they had to represent the will of $\operatorname{God}^{\prime \prime}(2002,5)$. As a result, in the play as in some historical accounts, questions of good and evil are overshadowed by the scale of his exploits and the power of his rhetoric and "symbolic claims" (a concept to which I will return). ${ }^{6}$

The moral ambiguity of Marlowe's hero heightened that already present in the histories, but neither the character nor the historical Timūr seem to have been imagined by early modern Europeans as physically other. The portraits of Timūr in Paolo Giovio's Elogia Virorum Bellica Virtute Illustria (1575), Richard Knolles's The Generall

\footnotetext{
${ }^{6}$ Manz points out that Timūr's campaign of self-legitimation was necessary since he was of lowly birth and thus "not eligible for supreme office" within either the Mongol or Islamic imperial traditions to which he belonged $(2002,3)$.
} 
Historie of the Turkes (1603), and in the first published version of the play (1590) look European. Indeed, the engraving in Knolles's account (see fig. 1) was accepted for decades as a portrait of the actor Edward Alleyn in the role of Tamburlaine, a claim effectively challenged by John $H$. Astington (1993). ${ }^{7}$ Similarly, Philip Henslowe's diary mentions the barbaric iron cage in which Bajazeth was imprisoned, but the costumes listed for Tamburlaine show that the hero's clothes resembled those of an Englishman of the time, not an exotic foreigner: "a cotte with coper [copper]

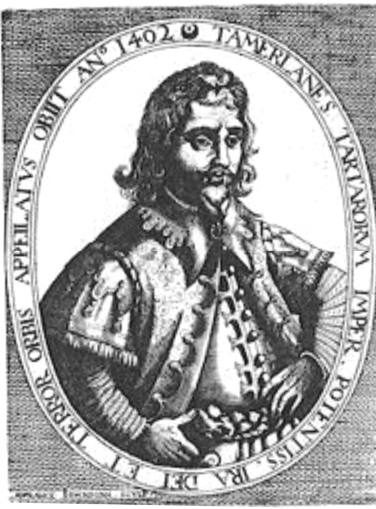

Fig. 1. Portrait of Tamburlaine in Richard Knolles, Generall Historie of the Turkes, 1603. lace" and "breches of crimson velvet" (quoted in Dawson 1997, xxx). As a Muslim, Timūr would have been seen as religiously other (although Tamburlaine's religion is ambiguous in Marlowe's play), but neither his physical attributes nor his dress differentiated him significantly from those of his early modern audience.

\section{After Marlowe: Timūr as William III, 1701-1800}

The plays that held the stage in the 170os differ markedly from Marlowe's play and most histories, embroiling Timūr in the love triangles and conflicts of honor that preoccupied Restoration tragedy, but in some ways, he is identified even more radically as "self" not "other."

In 1681, Charles Saunders published Tamerlane the Great, a dramatic treatment of the story. It appears to have been acted only a few times and saw no further editions. The subplot resembles the Gloucester/Edmund/Edgar plot in King Lear: Tamerlane is duped into mistrusting his good son and trusting the evil one. The play also

\footnotetext{
7 These and other early modern images of Tamburlaine can be found in Astington (1993, 73-86). Astington argues that the images (however conventional and derivative) are meant to depict Timūr himself. That Martin Holmes thought the image depicted Edward Alleyn indirectly testifies to the early modern artist's supposition that Timūr would have resembled an Anglo-European.
} 
features the vengeful ghost of the evil son's murdered wife. Saunders was accused of plagiarism, and his text has little literary merit. ${ }^{8}$ John Dryden wrote a bemused Epilogue stressing the "boypoet's" youth and "beardless" state, as if to excuse his lack of skill (Saunders 1681, 61). Nonetheless, the play indicates a late seventeenth-century interest in Timūr and portrays the son as more evil than the father.

While Saunders' play was stillborn, Nicholas Rowe's Tamerlane, A Tragedy had a long life. It saw thirty-five editions between 1701 and 1835, a record few Restoration or eighteenth-century tragedies can match (Burns 1966, 7). Rowe was a professional dramatist and produced the first edited collection of Shakespeare's works (1709). Rowe's hero, unlike Marlowe's, is the very model of a Christian prince. Knolles's account in The Generall Historie of the Turkes had portrayed a somewhat Christianized Timūr, but later writers went much further. ${ }^{9}$ In a 1690 essay on "Heroick Virtue," Sir William Temple declared that Timūr was "without question, a great Heroick Genius, of great Justice, exact Discipline, generous bounty, and much Piety, adoring one God, tho' he was neither Christian, Jew, or Mohametan" (quoted in Clark 1950, 146). Rowe's play echoes this view. Its debut featured the leading actors of the day: Thomas Betterton played Tamerlane, John Verburggen was Bajazet, and Elizabeth Barry and Anne Bracegirdle took the roles of Arpasia, Bajazeth's young wife, and Selima, his adult daughter.

The central conflict of Rowe's play is not between Tamerlane and Bajazet but between Bajazet and the Christian suitors, both in Tamerlane's service, who love the women Bajazet wants to control (Arpasia and Selima). To measure the difference between Rowe's Tamerlane and either the historical Timūr or Marlowe's hero, it is interesting to note what his play does not have: there are no Persians, no black flags and banners to terrorize populations, no talk of aspiring minds, no massacred virgins, no incinerated cities, no daily humiliation of Bajazet, and no iron cage - until Bajazet's outrageous

\footnotetext{
${ }^{8}$ Saunders claimed that he based his plot on a recent "Novell call'd Tamerlane and Asteria" (Saunders 1681, [a1v]). I have not been able to find this source, but Saunders' plot resembles the French play by Jaques Pradon (1675), the source for the opera librettos discussed in the next section.

${ }^{9}$ For a discussion of Knolles's positive portrayal of Timūr, see McJannet (2006, 124-27).
} 
acts force Tamerlane to punish him. Tamerlane's inner circle includes loyal Christians as well as sour (and sometimes treacherous) Tartars. Tamerlane's modesty and virtue are repeatedly displayed. For example, he responds to his generals' praise for the victory over Bajazet in language that echoes Macbeth (when he was still virtuous), King Lear on the heath, and Henry V after Agincourt:

It is too much, you dress me

Like an Usurper in the borrow'd Attributes

Of injured Heav'n: Can we call conquest ours?

Shall Man, this Pigmy, with a Giant's Pride

Vaunt of himself, and say, Thus have I done this?

[...]

Could I forget I am a Man, as thou art,

Would not the winter's cold, or summer's Heat,

Sickness, thirst, or Hunger [...]

$[\ldots]$

Reprove me daily? - No-If I boast of ought,

Be it, to have been Heaven's happy Instrument [...] (Burns 1966, 41-42)

By contrast, Rowe's Bajazet is a haughty and unpleasant figure. Initially, he maintains some dignity in his insistence that his soul is unbowed by defeat, but eventually he tries to kill his own daughter rather than let her marry Axalla, a Greek Christian. In fact, Bajazet (though already a prisoner when the play begins) commits the only violent acts in the play, and these actions are emphasized in the printed editions, which show him supervising the strangling of Moneses, the Greek nobleman who was betrothed to Arpasia before she was forced to marry the sultan, and threatening to kill his daughter Selima (figs. 2 and 3). By contrast, Tamerlane loses his temper only once, when Bajazet accuses him of trying to seduce his [Bajazet's] wife. A happy ending is secured for one of the couples, but the other falls victim to Bajazet's

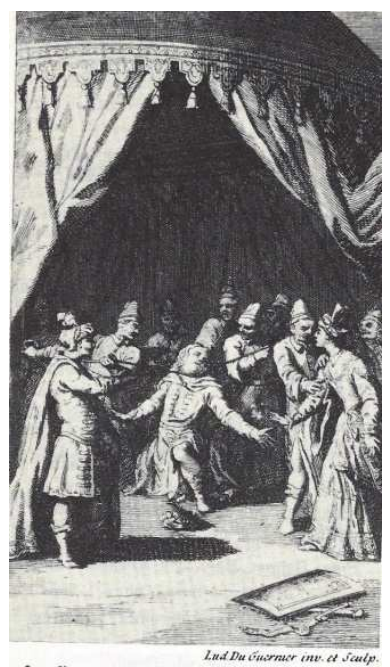

Fig. 2. Bajazeth looks on while the Mutes strangle Moneses and restrain the distraught Arpasia. From Nicholas Rowe, Tamerlane, $A$ Tragedy, fourth ed., 1717 . 
wrath. Caught in the act of attempting to murder Selima, Bajazet is finally imprisoned in the iron cage, where he can do no further harm.

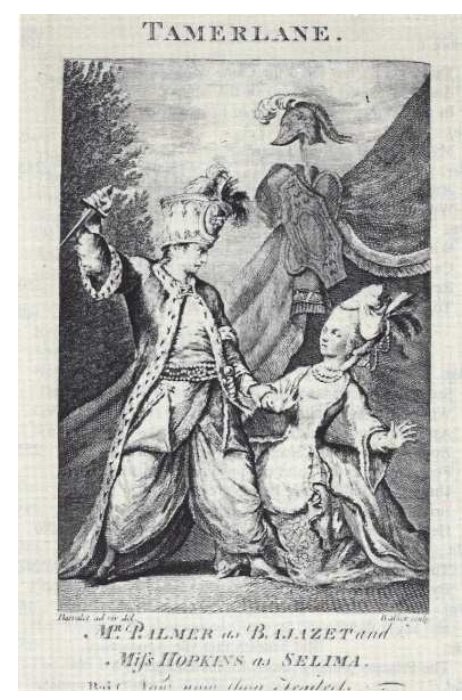

Fig. 3. Bajazeth (John Palmer) threatens his daughter Selima. From Nicholas Rowe, Tamerlane, A Tragedy, 1776 (and in later editions).

So, what does all this have to do with William III? Rowe's Tamerlane is so perfect a monarch that he was immediately read as an image of the king, who died the year that the play was published. Commentators saw a political allegory, with Tamerlane and his Christian commanders as William and the Whigs, upholding peace and justice at home and abroad, and Bajazet as Louis XIV, persecuting French Protestants and waging war against the Dutch (Burns 1966, 5). Rowe's Preface did nothing to dispel this interpretation..$^{10}$ Further, the corrupt dervish (or priest) and the disgruntled Tartar lords were seen as representing Jacobite Catholics and Tories. $^{11}$ Theatre managers began to mount the play every November 4, William's birthday, and November 5, Guy Fawkes Day and the anniversary of William's arrival in England in 1688 (Clark 1950, 146). Beginning in 1716 , the play was performed six to ten times a year for sixty years -an astonishing run (Burns 1966, 6). With a tamed Tamerlane, the play became a Whig ritual that celebrated their hero (William), maligned Tory rivals, and looked forward to continued influence and power.

\footnotetext{
${ }^{10}$ In his dedication, Rowe admits that his hero and the king share "many Features" including "Courage, [...] Piety, [...] Moderation, [...] and [...] Fatherly Love of [the] people, but above all, his Hate of Tyranny and Oppression, and his zealous Care for the common Good of Mankind." His portrayal, he insists, only shows "how far the Hero [William] has transcended the Poet's Thought" (Burns 1966, 17, italics in the original).

${ }^{11}$ Contemporaries also identified Axalla with Willem Bentinck, a trusted foreigner who served William, and the rebellious Omar with Lord Denby or the Earl of Godolphin (Thorp 1940, 125-126).
} 
Surprisingly, the extant editions boast six images of famous actors in the role of Bajazeth, but none of Tamerlane. ${ }^{12}$ The sultan's costume became increasingly oriental. His modest Turkish turban, tunic, and cloak in the edition of 1717 morph, in the 1792 edition, into a fanciful, feathered headdress, harem pants, and an erminetrimmed robe (figs. 2 and 3). Although the faces of mutes participating in the strangling are rather ghoulish, neither they nor Bajazet appear to be what we would call racially other. Since Tamerlane was identified with William III, it seems unlikely that either his physical appearance or his costume would have been more exotic than the sultan's. Dress, behavior, and cultural norms (strangulation by bowstring rather than beheading as a punishment for traitors) are emphasized, not the characters' physiognomy. In addition, only the male characters wore foreign costumes; the women wore fashionable dress of the day, decreasing the distance between the characters and the audience.

\section{Sympathy for the Sultan: Bayazid in Baroque Opera}

Adding to the familiarity of Timūr and Bayazid on the eighteenthcentury stage was Tamerlano, an opera written in London in 1724 by George Frideric Handel. In 1735, Antonio Vivaldi composed an opera with the same title, now called Bajazet in order to distinguish the two. In these works, the pendulum of sympathy swung back from Timūr to the Ottoman sultan. Both composers and their librettists relied on an earlier libretto by Agostino Piovene, itself based on a French play by Jacques Pradon published in 1675 . Handel's libretto, like its source, "takes the Turkish side":

It emphasizes the nobility of Bajazet as a put-upon hero who dies by his own hand, and the sufferings of his daughter Asteria, who becomes involved in a most Handelian love triangle with "enemies" Andronicus and Tamerlane. (Ashman 2010, 7)

According to Terence Best, Handel's changes to the libretto deepened sympathy for Bajazet. In Piovene's last scene, Bajazet "leaves the stage after his defiant aria [...] and takes poison"; in Handel's version, Bajazet has an extended on-stage death scene, which, "for pathos and dramatic power is unequalled in Baroque

${ }^{12}$ I checked all the illustrations in the editions contained in Early English Books Online. 
opera" (Best 2002, 12). Tamerlano, sung by an alto castrato (high tenor voice), is the villain. He jilts Irene to whom he was betrothed and threatens Asteria (Bajazet's daughter) with the murder of her Greek lover if she will not marry him. Everyone in the play flings negative epithets at Tamerlano ("that wretch," "unfaithful Tamerlano," "Fiend," "scoundrel," "Barbarian"). After misunderstandings and conflicts of honor, Irene and Asteria, displaying an understanding of dynastic politics and resourcefulness, chastise him by word and example. Stung by their just rebukes and Bajazet's tragic death, he relinquishes his claim to Asteria. In Handel's opera, the addition of powerful female roles and the complex love-plots reconfigure the balance of sympathy between Timūr and Bayazid to make the sultan the tragic hero. ${ }^{13}$

The marks of the characters' otherness in Handel's opera appear to be similar to those in Rowe's play. Burrows speculates that Eastern costumes and sets would have been part of the performance (2002, 11), but the original singers were all Italian, with Andrea Pacini, a famous alto castrato, as Tamerlano. ${ }^{14}$ So, once again, mise en scène was sufficient to transform a European cast into Ottomans, Central Asians, and Egyptians.

\section{Marlowe's Tamburlaine Returns, 1919- 2000}

Rowe's play disappeared from the stage during the nineteenth century, and Marlowe's Tamburlaine reemerged in the twentieth. In 1919, an abridged version played at Yale University, sponsored by the drama coach, Edgar Wooley (later famous as actor Monty Woolley), and his student, Stephen Vincent Benét. According to Nancy Leslie's analysis of the performance text, this "romantic" production imagined Tamburlaine as a "Robin-Hood-turned-

\footnotetext{
${ }^{13}$ Modern performances of Handel's work have emphasized its sympathy for the sultan. In a production by the Los Angeles Opera, Tamerlano was a "flighty-flippant sociopath [...]. A sort of [James] Bond villain on helium, or Dr. Evil with perfect pitch," while Placido Domingo sang a "compelling" Bajazet (Wallace 2009). When the production moved to London, critics again found Tamerlano a "lascivious tyrant," while Bajazet, sung by Kurt Streit (who replaced an ailing Domingo), possessed "a forthright, virile dignity" (Christiansen 2010).

${ }^{14}$ Burrows implies that Trevor Pinnock's production with The English Concert in 2001, with its Mongol, Ottoman, and ancient Egyptian costumes, might have approximated the original setting $(2002,11)$.
} 
Napoléon" and emphasized pageantry over poetry (1971, 112). Nonetheless, a young James Thurber and Shakespeare scholar C.F. Tucker Brooke praised the performance (Dawson 1997, xxx; Leslie 1971, 108). Neville Coghill and members of the Worcester [College] Buskins also mounted the play in 1933, and another Yale production is recorded in 1946 (Leslie 1971, 107.n4). These academic productions were influenced by the work of Harley Granville-Barker and other scholar-practioners, who sought to free Shakespearean drama from decades of Victorian traditions, including "grand" acting, heavily cut texts, an emphasis on spectacle, and interminable scene changes. The Marlowe Society, founded in 1907 at Cambridge University, inspired by the similar ideas of William Poel, dedicated itself to "verse speaking, clarity, intelligence of direction and acting, and a corresponding lack of emphasis on scenic spectacle" (Marlowe Society 2015). ${ }^{15}$ Although the Marlowe Society staged Doctor Faustus in 1907, it did not tackle Tamburlaine until 1993. Taken together, however, the university productions played an underappreciated role in the reintroduction of Tamburlaine to the theatre and in the revival of Marlowe and other early modern dramatists generally.

With Tyrone Guthrie's decision to open the Old Vic's 1951 season with Tamburlaine, Marlowe's play returned to the professional stage. Between 1950 and the end of the twentieth century, the play received nine professional productions (including Guthrie's), plus nine noncommercial performances, two $\mathrm{BBC}$ readings, and one radio broadcast of a new

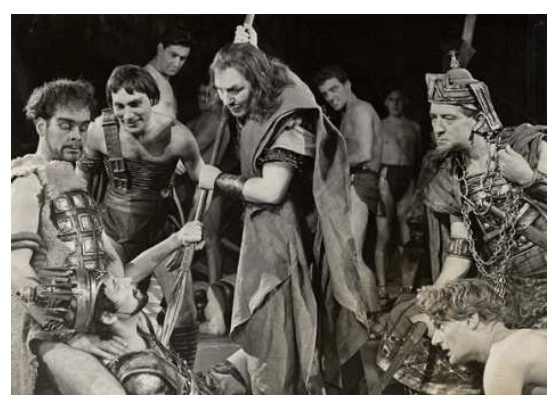

Fig. 4. Donald Wolfit in Tamburlaine the Great, 1951. (C) John Vickers/University of Bristol Theatre Collection/ArenaPAL. opera based on the play (see Appendix). The productions featured generic Eastern costumes and settings. While white actors (with a few exceptions to be discussed later) filled all the roles, as was the case in classic theatre at the time, Tamburlaine began to appear in

\footnotetext{
${ }^{15}$ The Society nurtured many prominent Shakespearean actors and directors: John Barton, Peter Hall, Trevor Nunn, Derek Jacobi, and Ian McKellan are all among its alumni.
} 
"oriental" makeup, and his cruelty was associated with markers of barbarism and cultural/racial otherness.

For example, in Guthrie's 1951 version, Tamburlaine, played by Donald Wolfit, threatens the Persian king Mycetes with a spear, while Cosroe looks on (fig. 4). Tamburlaine's costume differs from the Persians' civilized robes, but, as James Maloon pointed out, the costumes worn by his men were "about 1000 years too early": their wooly hides and bare limbs were more suitable for Attila the Hun than Timūr (Maloon 1977, 25). Guthrie's final scene depicted Tamburlaine as declining into animality: clad in a fur coat, Wolfit "prowled on all fours" over an immense map "like a fever-ravaged grizzly" (Leslie 1971, 114). Thus Guthrie exaggerated Tamburlaine's barbarism in relation to his antagonists in the play, as well as in relation to the audience. In addition, audiences and reviewers read

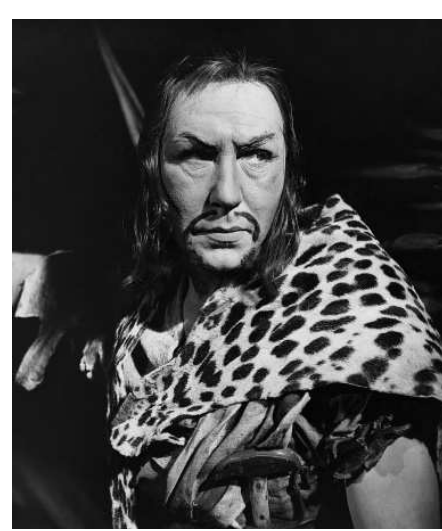

Fig. 5. Donald Wolfit in Tamburlaine the Great, 1951. Photograph by Maurice Ambler. (CHulton-Deutsch Collection/ CORBIS.

Wolfit's costume and make-up as "Mongolian," and it became more so in Part II (fig. 5). Eric Keown quipped that he "changed his hairdresser in the interval and acquired new Mongolian deviltry" (quoted in Maloon 1977, 18). Eric Johns also noted the "savage and repulsive" makeup and ascribed Tamburlaine's brutality in Part II with his "slip[ping] back toward his Mongol origins" (quoted in Maloon 1977, 18). Wolfit's moustache resembled that of the fictional Dr. Fu Manchu, the archvillain in a series of novels written by Sax Rohmer in the 1920 s and 1930s. ${ }^{16}$ The Fu Manchu craze is now seen as part of the reaction to the growing influence of China, the so-called Yellow Peril. The ethnic prejudices circulating at the time were also revealed by the reviewer for The Times, who observed that Wolfit's Tamburlaine displayed "a streetarab delight in cruelty" (Anon. 1951, 8). The off-hand, lower-case

\footnotetext{
${ }^{16}$ Sax Rohmer was the pen name and persona of Arthur Henry Ward (1883-1959). Fu Manchu's evil schemes circulated for decades in feature films, serials, comic strips, comic books, and radio dramas based on the novels.
} 
stereotyping ("street-arab") and the conflation of Mongolian and Arab peoples itself indicates a lack of interest in or knowledge of ethnic distinctions - an ignorance which this production seemed to exploit.

Guthrie's revival of this production in 1956, with Anthony Quayle as Tamburlaine, elicited similar prejudices. Coral Browne disappointed as Zabina, one critic wrote: she had not "sufficient force to do more than suggest oriental savagery: she [was] a western woman in a world of eastern barbarism" (Anon. 1956, 12). Interestingly, the same critic who associated Tamburlaine and his men with savagery and brutality (a not unfair response to this production) found Douglas Rain's Bajazeth full of "nobility" and endowed "with the wrath and majesty of a lion" (Anon. 1956, 12). So, at least one Eastern character was viewed positively. Scheduled for eight weeks in New York, Guthrie's revival lasted only twentyone performances. Maloon blames Guthrie's sensationalized direction and textual cuts, not his audiences, for this failure (1977, 24).

Peter Hall's 1976 production at the National Theatre took a similar approach, but achieved the opposite result. His allwhite cast included Albert Finney as Tamburlaine, Denis Quilley as Bajazeth, Susan Fleetwood as Zenocrate, and Barbara Jefford as Zabina. The costumes were opulent, silks studded with jewels. In this production, Bajazeth sported the black moustache, but it was less cartoonish than Wolfit's

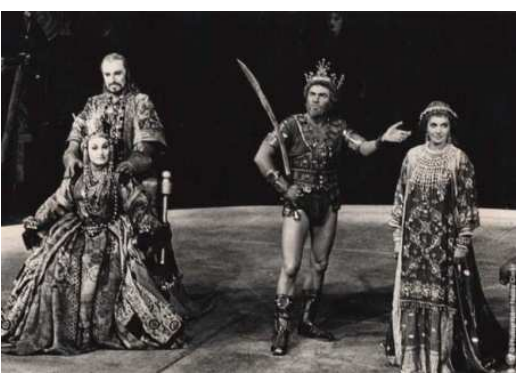

Fig. 6. Tamburlaine the Great, Act III, scene 3, with Barbara Jefford, Denis Quilley, Albert Finney, and Susan Fleetwood, National Theatre, 1976. CNobby Clark/ArenaPAL. (fig. 6). ${ }^{17}$ Finney's moustache was equally impressive but reddish brown (like the historical Timūr's), and therefore (apparently) not "repulsive and savage" as was Wolfit's. Tamburlaine was often bare-legged while Bajazeth was

${ }^{17}$ Contemporary images of the Ottomans, such as Gentile Bellini's portrait of Mehmet II, often show them with beards and moustaches, and some resemble the Fu Manchu style. 
robed, contrasting the more civilized Ottomans with the upstart hero. Critics also noticed Finney's "peasant swagger" and his "corner cockiness," observing tartly that Finney himself, unlike actors of the earlier generation, "ha[d] never seemed a gentleman" (Walker 1976). However, Hall's "detached, unjudging, and often humorous direction" resulted in a "dangerously attractive" hero, which would seem quite faithful to the play (Nightingale 1976, 73) ${ }^{18}$ In an additional contrast with Guthrie's production, Hall kept the battles off-stage and, used stylized effects, such as red spotlights for pools of blood, to suggest (rather than show) their violence. As a result, the savagery so pronounced in Guthrie's version was muted (Geckle 1978, 339). Still, like Guthrie, Hall introduced a less appealing Tamburlaine in Part II. Quilley's Bajazeth grew in stature and sympathy as the play progressed, achieving "the difficult task of making his defeat more moving than any of Tamburlaine's victories" (MacPherson 1976). In the second half, Finney acquired "a wildeyed" look, sufficiently different from his "fiery but engaging" demeanor in Part I to convey "an impending streak of madness" (Geckle 1978, 336). Thus, Hall included the trademark moustache but focused on Tamburlaine's mental instability rather than his ethnicity to explain the atrocities of Part II.

Terry Hands's 1992 production with Antony Sher for the Royal Shakespeare Company at the Swan Theatre found more problematic reference points for Tamburlaine's brutality. Sher, a white South African, had built his career playing the most sinister -and sometimes most other- of Shakespeare's characters: Richard III, Shylock, Iago, and Macbeth. Michael Billington wrote that he played Tamburlaine as a "bulging-eyed monomaniac with a Hitlerian dream of world conquest" $(1992,24)$. Hands's stated goal was to present "the human animal with its teeth bared" (quoted in Dawson 1997, xxxvii). He reportedly showed the actors videos of wild dogs hunting as a model for the behavior of Tamburlaine and his men.

${ }^{18}$ Based on the reviews and production photographs, I could imagine Finney's Tamburlaine, with his boyish charm, as the hero of Fielding's Tom Jones (1963), one of Finney's best film roles. 
Barbaric, yes, but Sher's Tamburlaine was a home-grown barbarian in a matted Mohawk hairstyle and a bandana (fig. 7). The bandana accounts for his description as "Rambo triumphant" (Wardle 1992), an allusion to the post-Vietnam vigilante played by Sylvester Stallone, whose hallmark (apart from his physique and machine gun) was a bloody bandana-headband.

In Hands's production, Bajazeth and his court entered on golden stilts wearing tusked helmets and long robes. Given Hands's metaphor of Tamburlaine as the leader of a hunting-pack, the tusked emperor seemed a natural prey - a slow-footed

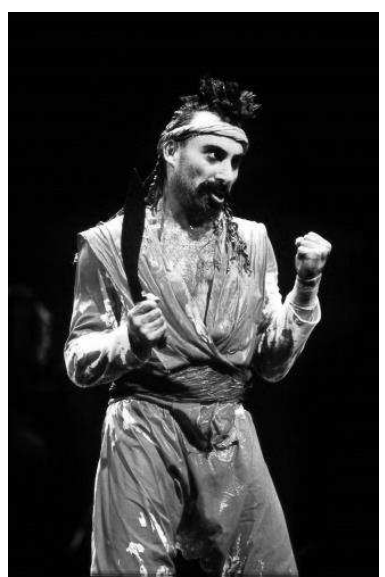

Fig. 7. Antony Sher, drenched in blood, as Tamburlaine, Royal Shakespeare Company, 1992-3. (c) Henrietta Butler/ ArenaPAL. water buffalo or an elephant cornered at the watering hole. When Bajazeth "snarl[ed]" at him, Tamburlaine responded with "tigerish roars," continuing the animalistic theme (Billington 1992, 24). Eventually, Sher kicked out the stilts, like a mischievous child, and toppled the sultan. Hands exacerbated Tamburlaine's barbarity with interpolated stage business. The banquet scene and the taunting of Bajazeth and Zabina included real cannibalism, not just the text's hypothetical allusions to it (Wardle 1992), and Tamburlaine's followers were allowed "to urinate over the morsels with which they taunt[ed] the starving [Bajazeth]" (Billington 1992, 24). ${ }^{19}$

Given this increase in the hero's savagery, the moment at which Sher became a "shaggy tribal chieftain, who leads his troops in footstamping chants and lethal high kicks" struck me as problematic (Billington 1992, 24). The movement sequence was created by South African playwright and director Welcome Msomi, who founded the Izulu Dance Theatre in 1965 and brought uMabatha or The Zulu Macbeth to London in 1972. Since high kicks are hallmarks of Zulu dances, some audience members may have inferred that

\footnotetext{
${ }^{19}$ Keith Hack had also introduced cannibalism in his production in Glasgow in 1972, so this detail was not original with Hands; see Wardle 1972, 15.
} 
Tamburlaine's barbarity could be conveyed —or even explainedby an association with Zulu dancing. In any case, the introduction of an African motif was a departure from previously oriental markers of Tamburlaine's otherness and pointed the way to the nontraditional casting that was to follow.

\section{Tamburlaine and BajAzeth: Black actors in the New Millennium}

In the twenty-first century, interest in staging Marlowe's play has grown. The last five decades of the twentieth century saw nine professional productions, nine university or non-commercial productions, two readings on the $\mathrm{BBC}$, and one opera broadcast; the first decade and a half of this century have already logged five professional, two non-commercial productions, one staged reading at Shakespeare's Globe, and four opera performances or recordings (see Appendix). No doubt, the attacks of September 11, 2001, the rise of brutal non-state terrorists, and the tragic sectarian violence in the Middle East and other parts of the world account for much of the play's current appeal: it features brutality as a political tactic and conflict among different Muslim groups as well as between Muslims and Christians. Moreover, in this century, Bajazeth, Tamburlaine, and other characters are likely to be played by actors of color. Casting actors of color in roles previously restricted to whites is a relatively recent phenomenon. It took centuries for white audiences to accept a black man in the role of black character such as Othello or Aaron, let alone Hamlet, Romeo, or Henry V. Joseph Papp's Shakespeare in the Park in New York pioneered the practice in the 1960s, and now it is becoming the norm especially in Britain. ${ }^{20}$ Simultaneously, and partly as a result of this practice, audiences for productions of Shakespeare and other classic dramatists have themselves become more diverse, altering the dynamics of identification among character, actor, and audience.

In her pioneering collection, Colorblind Shakespeare, Ayanna Thompson distinguishes between "colorblind casting" and "nontraditional casting." In colorblind casting, an actor's race is

\footnotetext{
${ }^{20}$ Ayanna Thompson discusses Papp's courageous but partial contribution to opening up Shakespearean performances to actors of color (2006, 1, 4-5).
} 
assumed to be irrelevant to his or her suitability for a role. Applying this principle opened the closed world of Shakespearean performance to actors of color. In practice, however, colorblind casting had some unwritten rules: if the hero was black, so was his love interest (no "interracial romantic couples"), and families likewise had to be "monochromatic" (Thompson 2006, 9). Thompson argues, further, that audiences can never really be blind to race in contemporary society, and that the attempt to make race invisible, as E. Patrick Johnson has written, risks ignoring or devaluing the fact that "the black body has historically been the site of violence and trauma" (quoted in Thompson 2006, 15). Reviewers of early colorblind productions were uncertain whether to note an actor's race; if race was irrelevant, it seemed inappropriate to mention it (Thompson 2006, 9). As a result, as I have discovered, tracking this trend can be difficult. ${ }^{21}$ Nontraditional casting, on the other hand, uses the actor's race deliberately to make a socio-political point or to add another layer to characterization or theme. It doesn't pretend race is invisible; rather, it leverages the historical and cultural associations of race to create timely new meanings. However, as Thompson points out, the "significance of an actor's race is perpetually in flux," so intended meanings must be established in the performance itself and may or may not be successfully communicated. In her view, neither colorblind nor nontraditional casting can therefore never be entirely "free from the specter of racism" —or from racist interpretation $(2006,8)$.

Both colorblind and nontraditional casting have had their critics, most notably the late African American playwright August Wilson, whose award-winning plays document a century of American history as experienced by African Americans. Wilson viewed colorblind casting of classic plays as another way to make blackness invisible, to elevate the cultural capital of white writers, and to entrench Shakespearean roles as the crowning achievement for an actor (Thompson 2006, 1). Peter Erickson questions the term "colorblind" itself on the grounds that it appears to avoid discussion of whiteness and to assume (in Patricia Williams's phrase) "a

\footnotetext{
${ }^{21}$ Some reviewers include a photograph that clarifies the casting, and visiting the actors' websites can be helpful. But even then, one is confronted with the infinite variety of human appearance and a photograph may or may not accurately convey how a particular person identifies him- or herself with respect to race or ethnicity.
} 
prematurely imagined community" in which all races have an equal place $(2006,242)$. Referring to Denzel Washington, who played Don Pedro in Kenneth Branagh's Much Ado about Nothing, Erickson asks, "How can we be colorblind if [...] the character excluded from the marital festivity [at the end] is played by the actor who just happens to be black?" (2006, 248 n.19). As an alternative, Thompson embraces ethnographer Dwight Conquergood's concept of Bakhtinian, "dialogical performances" that would "bring self and other together so that they can question, debate, and challenge one another" (quoted in Thompson 2006, 17). Far from being blind to race, such performances would be committed to the dialogue between actor and text. They would discard the unwritten conventions of colorblind casting and encourage audience members and critics "not to be afraid to discuss moments in a production that [made] them uncomfortable" (Thompson 2006, 17). While this model remains somewhat abstract and might not satisfy Wilson, it resembles Erickson's call to view cross-racial casting (the term he prefers) as an "explicit metadramatic theme whose interpretation is crucial to a [production's] overall meaning" (2006, 242).

Thompson's and Erickson's insights can illuminate the ways that actors of color, and particularly actors of African ancestry, have been cast in recent productions of Tamburlaine. While it is not a simple linear progression, one can see examples of colorblind, nontraditional, and perhaps even dialogical cross-racial casting. In addition to race, contemporary productions also highlight the play's Muslim milieu and the characters' religious identity. The success of such decisions (like everything else in a production) can be determined only case-by-case, preferably after multiple viewings. Consequently, I will briefly survey critics' reactions to productions I did not see and concentrate on the 2014-2015 production directed by Michael Boyd, which I was able to see twice, and with some of whose actors I was able to speak after the performances. I do not presume to speak for all white, female, Scots-Irish-Franco-American, lapsed Catholic spectators (such as myself), much less for the diverse urban audiences who saw these productions. However, while earlier productions clearly opened up Marlowe's play to new actors and new meanings, my experience of Boyd's production came closest to the dialogical ideal Thompson envisions. 
Actors of color first appeared in supporting roles. ${ }^{22}$ Claire Benedict, a native of Antigua, W.I., played Zenocrate to Antony Sher's Tamburlaine in 1992/3. This added race to their social and ethnic differences (she a princess from an ancient state and culture, he an upstart nomadic warrior) and created an interracial couple, one of Thompson's benchmarks for fully nontraditional casting. As noted above, Hands also included a Zulu-like dance sequence, but this ethnic touch was associated with Tamburlaine and his men, not Zenocrate.

Bajazeth was the first major character to be played by a black actor. In 1999 at Covent Garden, Samantha Shammas cast a black English actor, Jason Barnett, opposite a white Tamburlaine (Brendan Fleming). The actress playing Zabina (Iona Grant) was also black, while Zenocrate (Catherine Harvey) was white, so this production did not feature interracial couples. ${ }^{23}$ Rather, two couples of contrasting ancestry squared off in their battle for empire. Less comprehensible was the presence of "a high steel fence peppered with more than 300 blood-spattered [black] dolls" (Shammas 1999). The dolls in the production photographs initially bore some resemblance to Benin sculptures, but on closer inspection they seemed to be black Kewpie dolls. Strung up even before the massacre of the Virgins or the fate of the Governor of Babylon, they seemed to point forward to Tamburlaine's bloodiest acts. Perhaps they signified all the lives lost in his murderous campaigns, or perhaps they were meant to represent religious totems, but in either case their blackness remained puzzling. Ben Naylor's 2003 production at the Rose Theatre featured Ghanian-born Kwaku Ankomah as a "terrifying and majestic" Bajazeth opposite lightskinned, Egyptian-born Khalid Abdalla as Tamburlaine (Violanti 2004, 124). Once again, race as well as politics separated the rivals.

\footnotetext{
${ }^{22}$ In describing the effects of cross-racial casting, I will necessarily focus on the markers audiences would see and hear, such as skin tone or accents from the actors' countries of origin or ancestry. I have not been able to determine how specific actors might identify themselves (except where they are on record, like John Douglas Thompson). I recognize that markers of social and racial difference exist to uphold hierarchies of power, and I hope my analysis will be able to discuss some of the points of discomfort Thompson mentions, without creating discomfort in others. I will appreciate hearing about my failures.

${ }^{23}$ I base this assertion on the photograph of the two queens confronting each other on the director's website (Shammas 1999).
} 
Naylor also included Muslim costumes, such as the burqa worn by the (single) Virgin of Damascus (Violanti 2004, 123). Finally, in 2005 at the Bristol Old Vic and later at the Barbican in London, David Farr directed Trinidad-born Jeffrey Kissoon as Bajazeth opposite a white Tamburlaine (Greg Hicks). The Anglo African actress Ann Ogbomo was Zabina, so the sultan and his wife were bound by ancestry as well as mutual devotion. Tamburlaine's men initially appeared in sheepskins, but their costumes later became "conventionally transhistorical," blending chain-mail shirts with "twenty-firstcentury guerilla garb"; the Virgins again wore quasi-Muslim dress, "white cheesecloth-like burqas" (Shand 2006, 50-51).

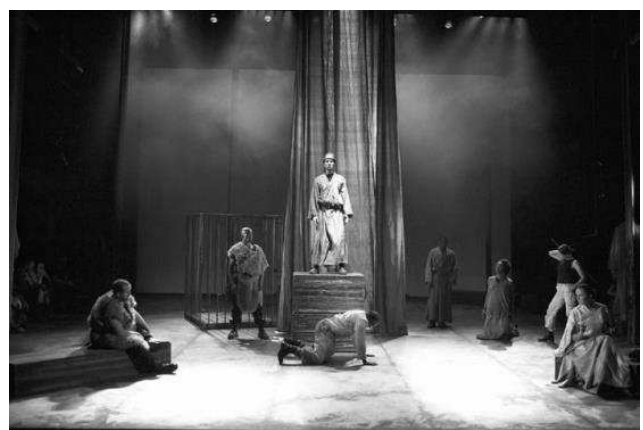

Fig. 8. Greg Hicks as Tamburlaine and Jeffrey Kissoon as Bajazeth, Bristol Old Vic, 2005. (C) Manuel Harlan.

Given the casting of these three productions, the tableau of a white Tamburlaine mounting his throne on the back of a kneeling black Bajazeth would have carried extra significance (fig. 8.) Evoking the history of slavery and colonialism, it invited audience members to identify uncomfortably with Tamburlaine, the white oppressor, or (with guilt or sympathy) with his black victim —or all of the above. Farr also cast Nigerian-born Chukwudi Iwuji as the Persian captain Theridamas, one of Tamburlaine's trusted commanders. This casting also seemed purposeful, suggesting that black as well as white fighters had rallied to Tamburlaine's cause. At the same time, Iwuji conveyed discomfort with Tamburlaine's cruelest actions; he was "no unquestioning henchman" (Keenan 2006, para.13). Farr thus distributed feelings of resistance among actors/characters of different races and genders, the black Theridamas and the white Zenocrate, whose dismay at some of her husband's actions was heightened in this production (Shand 2006, 51). 
In addition to playing Bajazeth in 2005, Jeffrey Kissoon was the first black actor to play Tamburlaine himself —or a piece of him. In the 1972 Glasgow Citizens' Theatre version directed by Keith Hack, Kissoon was one of three actors who took the role, one in each act. Wardle wrote that this arrangement did not convey any character progression or contribute to the meaning of the production, but his own comments belie his assertion. He characterized the three actors as providing a developmental arc for the hero and associated Kissoon's race with Tamburlaine's more negative acts. As he put it, Rupert Frazer played Tamburlaine as "an erotic adventurer" and Kissoon as "a brutal dusky killer," while Mike Gwilym acquired "something like Marlovian dignity and sonority" (Wardle 1972, 15). In the eye of this critic, Kissoon's race became associated with Tamburlaine's bloody acts and reinforced negative stereotypes.

Only in 2007 did a black actor undertake the entire lead role. Michael Kahn's Shakespeare Theatre Company in Washington, D.C., featured African American actor Avery Brooks as Tamburlaine and a multiracial cast. There were several interracial couples: Theridamas (Scott Jaeck) was white and Olympia (Amy Kim Waschke) was Asian American; Bajzaeth (David

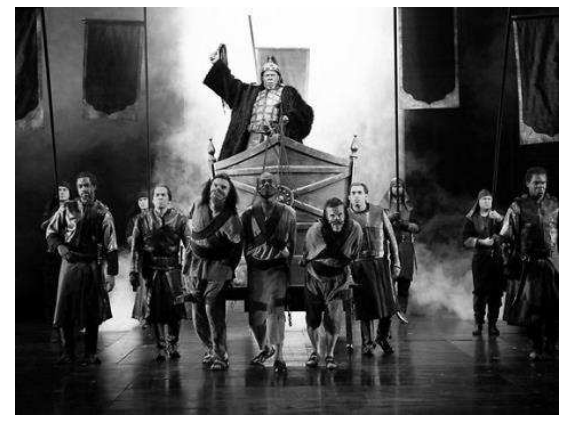

Fig. 9. Avery Brooks as Tamburlaine, 2007. Photograph by Carol Rosegg. (The Shakespeare Theatre Company.

McCann) was white and Zabina (Franchelle Stewart Dorn) was African American; and Tamburlaine (Brooks) played opposite Mia Tagano (Zenocrate), who describes herself as "Japanese, Armenian, and German" (Tagano [2015]). Tamburlaine's sons were plausibly biracial, with their mother's eyes, and a skin tone lighter than their father's, so two of the unspoken limits of colorblind casting were

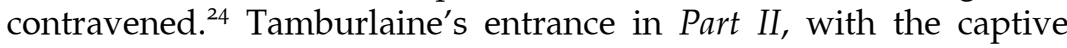

\footnotetext{
${ }^{24}$ Historically, an Ottoman sultan's wife or favored concubine might indeed have been of a different ethnicity. Muslim women were protected from concubinage, and captured non-Muslim women often rose to positions of influence. Süleyman the Magnificent's wife, Roxolana, was of Circassian or Russian descent. So this instance of cross-racial casting could have been a nod to history.
} 
kings pulling his chariot, was spectacularly realized with a large war wagon, a diverse band of warriors and enslaved kings, and black banners presaging the destruction of Babylon (fig. 9).

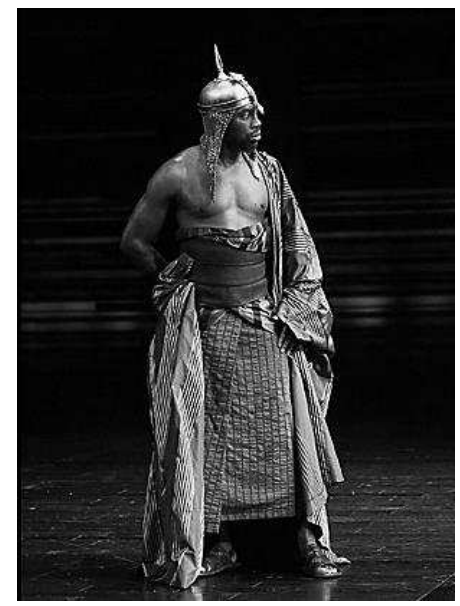

Fig. 10. Soldier with helmet, leather "obi-style" belt or armor, and striped and block printed cotton robes. Photograph by Carol Rosegg. CThe Shakespeare Theatre Company.
In keeping with the racially diverse cast, the production was eclectically designed. Tamburlaine initially wore nomadic leather and fur that contrasted with the Turks' and Persians' silks and turbans. Soldiers sported Central Asian helmets as well as obi-like leather belts and striped cotton robes (see fig. 10). Olympia's and Zenocrate's East Asian identities were reflected in two taiko drums suspended on the rear wall of the stage and the antique Chinese canopy bed on which Olympia tricked Theridamas into ending her life. The play's Islamic milieu was not emphasized, however. Lois Potter observed that the play, with its Muslim characters and provocative scenes (such as the burning of the Koran in Part II), is arguably so "contemporary as to be almost unplayable"; she felt that Kahn opted for "remoteness and beauty as if afraid of what would happen if he pushed the topicality too far" (2009, 64-65). Nonetheless, Kahn retained the burning of "an oversized Koran" (Godwin 2009, 126), a scene which had been "neuter[ed]" in Farr's production by the substitution of "unidentified 'holy books'" (Shand 2006, 49). Overall, Laura Grace Godwin criticized Kahn's production for not living up to its own splendor - or to the complexity of Marlowe's text. In her view, Kahn reduced the play to a "live-action video game pitting one exotically named and dressed ruler against another" (2009, 126).

Brooks had played Othello for Kahn's company and was also known for his television work as Hawk, the hard-boiled detective in Spenser for Hire and as Captain Sisko in Star Trek: Deep Space Nine. Critics praised his deep and powerful voice and invoked the memory of Paul Robeson, African American opera star, actor, and 
activist (Godwin 2009, 125; McCauley 2010). Godwin praised his work as Othello and acknowledged that he would have seemed "an excellent choice" for the part (2009, 125), but she was severely critical of his performance and Kahn's direction. Tamburlaine's dialogue, she wrote, "was never clearly enunciated, and [...] it was usually punctuated by animalistic growls [...] and a vigorous shaking of the body, with the result that undecipherable non-verbal messages regularly obscured the content of Marlowe's mighty lines" (2009, 125). She faulted the director for undercutting Tamburlaine's stature by depicting Bajazeth as "an English pantomime emperor straight out of a West End production of Aladdin" (2009, 126). (Before his defeat, Bajazeth lounged on a divan with a turban and muttonchop facial hair, resembling a Victorian gentleman in smoking jacket more than the Ottoman sultan known as the Lightning Bolt [fig. 11]. ${ }^{25}$ )

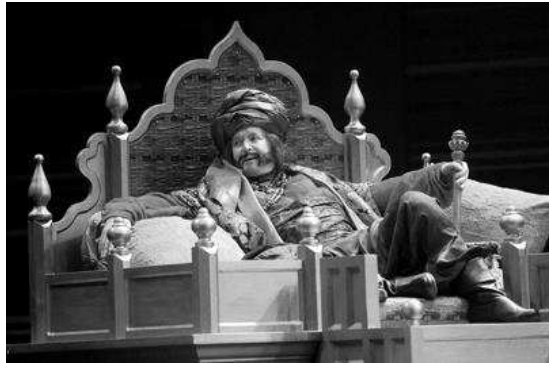

Fig. 11. David McCann as Bajazeth with mutton-chops, reclining on his throne, 2007. Photograph by Carol Rosegg. OThe Shakespeare Theatre Company.

Godwin's comments about Brooks's performance carry an unfortunate historical sting. As Thompson points out, black actors had been excluded from Shakespearean and other classical roles for their alleged inability to speak and understand Shakespeare's language; it was a "litmus test" used to disqualify them in advance $(2006,2)$. I did not see Brooks in the role, so I cannot confirm or contradict the description of his delivery, and Godwin is a respected critic, whose views appear regularly in Shakespeare Bulletin and other journals. In considering the specifics she mentions, it is important to recall that "animalistic" details had been associated with white actors, too: Antony Sher roared like a tiger (Billington 1992, 24); Sher's Turkish opponents bellowed like elephants (Tasnim 2012); and Wolfit in his final scene crawled across the stage like a wounded

\footnotetext{
${ }^{25}$ The painted-on Fu Manchu moustache was demoted and appeared only on Mycetes, the foolish Persian monarch.
} 
bear (Leslie 1971, 114). Nonetheless, Godwin's criticism (true or not) strikes the ear differently when it concerns an actor of color. This is not to say that a reviewer should not speak his or her mind. As noted earlier, in Colorblind Shakespeare Thompson exhorts spectators, actors, and critics alike to speak honestly, but this example illustrates the challenges all parties face in discussing nontraditional casting. In this case, it seems, Kahn created a visually beautiful, multicultural world for Marlowe's hero, where interracial couples and mixed race families were the norm, but Brooks may have been miscast and was apparently not well served by Kahn's direction.

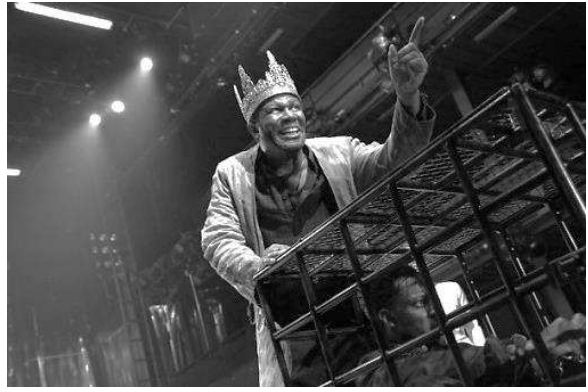

Fig. 12. Douglas Thompson as Tamburlaine, Chukwuji Iwuji as Bajazeth, Theatre for a New Audience, 2014. (CGerry Goodstein.

In 2014, Michael Boyd also cast a black actor, John Douglas Thompson, as Tamburlaine in production at the Polansky Shakespeare Center at the Theatre for a New Audience in Brooklyn, NY (fig. 12). Thompson was born in the UK, educated in the US, and identifies himself as a CanadianAmerican. Unlike Brooks, Thompson's career

developed in the theatre, including the Royal Shakespeare Company and other prestigious venues. Boyd, like Kahn, included many actors of color in the cast, so neither Brooks nor Thompson was a token black in an all-white cast. Rather, both casts conveyed the global scale of the contest for empire. Chukwudi Iwuji (Theridamas in Farr's production) played Bajazeth, and Jamaican-born Patrice Johnson Chevannes was Zabina. Thus, this couple was not interracial, but Zenocrate (Merrit Janson) was white, and her children with Tamburlaine had varied skin tones: one dark, one white, and one in-between. I read this as true-to-life; children of interracial marriages may resemble one parent more than another. But at least one critic read it differently. Joel Dodson judged Thompson's Tamburlaine "terrific" in Part I, but he observed that the hero seemed "unaware [in Part II] that two of his three sons look[ed] 
conspicuously more like his generals than himself" $(2014,8) .{ }^{26}$ Our different interpretations illustrate Thompson's point that the significance of an actor's race on stage is neither fixed nor easily controlled. Similarly, in this production, Calyphas (James Odom), the son who rejected his father's warlike ethos and died at his hands, closely resembled his father physically, while Amyras (Zachary Infante), the son who succeeded Tamburlaine, was smaller in stature and lighter-skinned. ${ }^{27} \mathrm{I}$ felt the casting challenged simplistic assumptions about inheritance and physical versus temperamental leadership qualities; others may have seen not irony but stereotyping at work.

Overall, Boyd's casting seemed strategic and dialogical, not merely colorblind. Of the actors playing Tamburlaine's victims, about half were white and half were not; his closest comrades in arms, Usumcasane (Carlo Alban), Techelles (Keith Randolph Smith), and Theridamas (Andrew Hovelson) were of different ages and ethnicities. While Thompson is

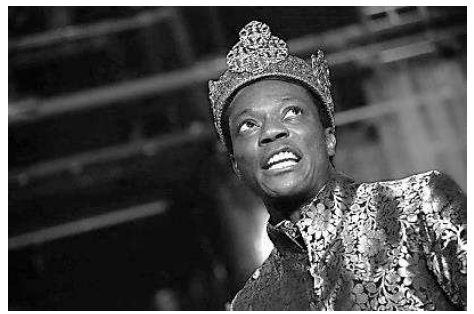

Fig. 13. Chukwudi Iwuji as an elegant Bajazeth, Theatre for a New Audience, 2014. (OGerry Goodstein. "classically trained" (a term rather irritatingly repeated in many of reviews of this performance), he employed the voice, gestures, and body language typical of a more or less contemporary American. ${ }^{28}$ According to one reviewer, he played the part "with drawling wit and vigour," "more like a tough contemporary cop [...] than a wellspoken [...] Marlovian protagonist" (Fisher 2014, 2). Though he avoided a self-conscious vocal delivery, Thompson was totally at ease with —and the master of- Marlowe's language, just as he was

\footnotetext{
${ }^{26}$ Dodson's comment seems to overlook the fact that several of Tamburlaine's generals (including Techelles and Usumcasane) were also played by actors of color, although their skin tones were lighter than the hero's.

${ }^{27}$ Sitting in the second row, I felt how intensely Infante inhabited his role as he locked eyes with members of the audience, while Tamburlaine threatened the citizens of Babylon.

${ }^{28}$ The phrase "classically trained" or "classical actor" was used by Simon, Barbour, Brantley, and Croghan. It uncomfortably resembled white journalists describing a person of color as "articulate" or "well spoken," as if the quality were unusual. No reviewer used such a descriptor for Wolfit, Finney, or Sher.
} 
physically dominant and at ease in his body. Whereas Thompson's Tamburlaine sounded American, Bajazeth and Zabina had British accents. Their costumes were of golden silk brocade, elegant and fitted, in contrast to Tamburlaine's loose, military-style great coat (fig. 13). Thompson gestured expansively, whereas the Ottoman emperor and his wife moved precisely and formally, holding their bodies erect, reinforcing the social distance between themselves and Tamburlaine. Boyd's direction thus explored nuances of privilege and power within a racial group, suggesting that race itself is not the only social barrier.

More than Kahn, Boyd stressed the religious elements of the play. The Christians in Part II (who were cut by Kahn) carried large crosses into battle. When the Christian Sigismund and the Muslim Orcanes agreed to a truce, they emphasized the names by which they swore, hitting the consonants with competitive force: "Jesus Christ" and "sacred Mahomet." Also religiously pointed was the massacre of the Virgins at Damascus. Two of the women wore hijabs or khimars (long cape-like veils) over loose black garments, and one wore a more concealing niqab or burqa, which conveniently disguised the male actor who filled out their numbers. In a stunning effect, their deaths were conveyed by streams of blood, running down the strips of translucent PVC behind which they stood (see fig. 14). There was no escaping the fact the Tamburlaine was destroying fellow Muslims. Similarly, when Tamburlaine prepared to burn the Koran, the captive Muslim kings protested with horror, underscoring their reverence for the holy book. Recalling recent anti-Muslim provocations, flash paper ignited spectacularly, and ashes wafted down upon the stage.

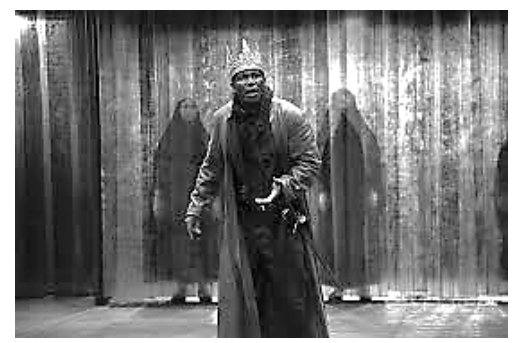

Fig. 14. The death of the Virgins of Damascus, with John Douglas Thompson as Tamburlaine, Theatre for a New Audience, 2014. CGerry Goodstein. 
As the production progressed, the costumes and props crept closer to modern times. Machine guns and pistols replaced daggers and scimitars, and, as in other productions, Tamburlaine became less sympathetic. In act 5, he confronted audience members as if they were the besieged people of Babylon. As he rolled in on his war wagon (which had doubled as Bajazeth's cage), his sons and others hung off the sides of the vehicle, brandishing AK47s. The effect was right out of the headlines, which were full of ISIS fighters in pick-up trucks, who had defeated Middle Eastern armies and declared their Caliphate. ISIS's very name - the Islamic State- constitutes a symbolic claim that recalls Manz's account of Timūr's selflegitimation. Like the historical Timūr and Marlowe's hero, modern terrorists use rhetorical claims and staged violence to create their own reality. An uncanny moment occurred when Tamburlaine cut his arm and ordered his sons to bathe their hands in his blood. As his "good" sons eagerly obeyed, I was reminded of how boys who had escaped from ISIS described their training. According to one young recruit, the teacher showed them how to behead a prisoner and asked for volunteers to perform the act on a living captive: "The youngest boys' hands shot up, and several were chosen to participate. 'I'd become desensitized by then,' the young man reported. "The beheading videos they'd showed us helped'" (AbiHabib 2014, A1). As one critic noted, in Boyd's production, "the history of the present moment [became] a co-author, adding its own expressive footnotes [...] without any directorial intervention" (O'Brien 2014).

Taken together, these examples of a black Tamburlaine (and/or a black Bajazeth) resonate in multiple ways. One may feel uneasy that so violent and brutal a character is among the first classical roles offered to black actors and that some critics saw racial stereotypes enacted. On the other hand, Thompson's performance was universally hailed, as a "force of nature" (Brantley 2014, $\mathrm{C}_{1}$ ). He was praised for finding nuances in the hero, without compromising his defiance of all conventional morality ( $\mathrm{O}^{\prime}$ Brien 2014). None of the previous white actors was seen as achieving comparable complexity. Similarly, critics agreed that Iwuji and Chevannes rescued Bajazeth and Zabina from their supposed bluster to create noble, sympathetic opponents for Tamburlaine. Further, in practical terms, Tamburlaine 
and Bajazeth are leading roles - as well as great roles- from a major play in the repertoire. They are prizes to be sought - not to mention paychecks to be welcomed. To play either of these characters is a mark of excellence and accomplishment as an actor. Audiences are aware of these practical and professional considerations, and (I speculate) many viewers can separate the actor from the role, which is, I would argue, distinct from being "blind" to an actor's race. When I spoke with some of Boyd's cast, this was their implicit view of the matter. They were proud to be in such an excellent production and reveled in the reception of Thompson's performance as Tamburlaine, as well as the raves received by Iwuji, Chevannes, and Keith Randoph Smith, among others. They were more interested in matters of craft than in discussing the implications of cross-racial casting or points of contact with contemporary events: Had I picked up on the logic of the doubling of Zenocrate and Callapine, or of Bajazeth and Zabina's return as the kings of Trebizon and Syria in Part II? The subtleties of cross-racial casting and the parallels with contemporary events they seemed to take as givens, as aspects of the performance that the audience was welcome to interpret on its own.

If black Tamburlaines and Bajazeths and multiracial casts can create new meanings and insights in performances of Marlowe's text, what might be the result of a mostly Asian cast or a historically accurate production, in which actors of Persian, Arab, Turkish, Egyptians, North African, and Central Asian descent took the parts of their ancestors? ${ }^{29}$ Could such a production be done in our historical moment? Would it be an overdue rebuttal of the Yellow Peril productions of the previous century, or a reactionary retreat to bogus historical fidelity? To be sure, it would raise the question of which kind of Arab or Egyptian or Central Asian would appear. These terms, like "Black" or "Latino" or "Asian" in our own lexicon, refer to communities that are not monolithic or fixed. Moreover, our understanding of the intermixture of cultures and races in those distant places at that distant time is far from perfect. Still, having

\footnotetext{
${ }^{29}$ In 1989, Antonio Diaz-Florian directed a production at the Théâtre de l'Épee de Bois in Paris that featured actors from North Africa, the Middle East, and South America. Dias-Florian, a Peruvian, played Tamburlaine (in most convincing fashion, judging from production photographs), and the common denominator for the cast was the experience of despotism and exile, not a shared ancestry with their characters. The mise en scène was eclectic, mixing turbans and great coats, and the acting was deliberately stylized and anti-realistic (Singleton 1991, 83 and 90-94).
} 
admired the historically informed costumes in Kahn's production, I would love to see such a realization of the text and to think about its contemporary resonances. Such a production would establish, at the very least, that Tamburlaine's army was far from being a primitive band of half-naked marauders. His nomadic culture was highly adapted to its geographical niche, and his camp resembled a well laid out city, with streets assigned to the armorers, bakers, tanners, and other craftspeople who travelled with the army and sustained it. The fabrics, carpets, metalwork, and other artifacts associated with his culture and the commerce of the Silk Road would give quite a different impression from the primitive sheepskins depicted in many productions. What if the conqueror were envisioned in his own terms, not under the trope of the barbarian?

The figure of Timūr has a long and varied history on the Western stage. It has oscillated between implacable barbarian and ideal ruler, declined into parody, and returned to take its place among the most challenging and relevant of early modern roles. Spurred by the savagery of modern history, theater practitioners have found contemporary analogues, from stereotyped racial others like $\mathrm{Fu}$ Manchu, to the power-mad dictators of World War II, to the terrorists who attacked Parisian cafés, Beirut neighborhoods, the Brussels airport, and a Pakistani park as I was completing this essay. Like the historical Timūr, Marlowe's hero embodies disturbing truths about the psychology of terror, the power of symbolic political claims, and the ability of staged brutality to undo, for a time or forever, years of socialization. Of late, cross-racial casting and religious specificity have contributed to the play's vitality, and one can hope that courageous directors and performers will continue to explore its themes, even if audiences react with discomfort. As one critic observed of Boyd's production, "The energies unleashed [in the play] are destructive and uncontainable - [and] if that effect is not produced, there is not much point in doing the thing in the first place" (O'Brien 2014). The power and continuing relevance of Marlowe's play having been reestablished, one hopes that Timūr's theatrical journey has not yet reached its end. 


\section{Appendix. Modern Productions of Marlowe's Tamburlaine and Related Works with Directors and Venues}

Note: Non-commercial productions may feature professional, even prominent, actors and directors.

1950-2000

PROFESSIONAL

\begin{tabular}{|c|c|c|}
\hline 1951 & Tyrone Guthrie & Old Vic, London, UK \\
\hline 1956 & Tyrone Guthrie & $\begin{array}{l}\text { Toronto, Canada, and New York, } \\
\text { USA }\end{array}$ \\
\hline 1964 & Robert Pennant Jones & Tower Theatre, London, UK \\
\hline 1966 & R. D. Smith & $\begin{array}{l}\text { Marlowe Theatre Arena, Canterbury, } \\
\text { UK }\end{array}$ \\
\hline 972 & Keith Hack & $\begin{array}{l}\text { Glasgow Citizens' Theatre, Glasgow, } \\
\text { UK }\end{array}$ \\
\hline 1976 & Peter Hall & National Theatre, London, UK \\
\hline 1983 & Mik Derks & $\begin{array}{l}\text { American Players' Theatre, Spring } \\
\text { Green, WI, USA }\end{array}$ \\
\hline $1992 / 3$ & Terry Hands & $\begin{array}{l}\text { Swan Theatre, Stratford-upon-Avon } \\
\text { and Barbicon Theatre, London, UK }\end{array}$ \\
\hline 1999 & Samantha Shammas & Cochrane Theatre, London, UK \\
\hline \multicolumn{3}{|c|}{ UNIVERSITY OR NON-COMMERCIAL } \\
\hline 1958 & unknown & $\begin{array}{l}\text { Peninsula Theatre, San Mateo, CA, } \\
\text { USA }\end{array}$ \\
\hline 1960 & John Duncan & Oxford University, UK \\
\hline 1964 & unknown & $\begin{array}{l}\text { Corpus Christi College, Cambridge } \\
\text { University, UK }\end{array}$ \\
\hline 1968 & unknown & Group One, Birmingham, UK \\
\hline 1971 & unknown & University of York, UK \\
\hline 1975 & Tim Sewell & Oriel College, Oxford University, UK \\
\hline 1989 & Antonio Diaz-Florian & $\begin{array}{l}\text { Théâtre de l'Épee de Bois, Paris, } \\
\text { France }^{30}\end{array}$ \\
\hline 93 & Tim Supple & $\begin{array}{l}\text { Marlowe Society, Cambridge } \\
\text { University, UK }\end{array}$ \\
\hline
\end{tabular}

\footnotetext{
${ }^{30}$ My research concentrated on Anglophone productions, but this French production was kindly called to my attention by one of the referees of this essay. There are no doubt other interesting non-Anglophone productions of which I am not aware.
} 


$$
\text { Gederi } 26 \text { (2016) }
$$

1997 Jeff Dailey (Part I) American Theatre of Actors, New York, USA

RADIO BROADCASTS OF READING OR OPERAS

$\begin{array}{ll}1964 & \mathrm{BBC}^{1} \\ 1965 & \mathrm{BBC}_{3} \\ 1977 & \text { BBC }_{3} \text { Ian Hamilton }\end{array}$

2001-2015

PROFESSIONAL

$\begin{array}{ll}2003 & \text { Ben Naylor } \\ 2005 & \text { David Farr } \\ 2007 & \text { Michael Kahn } \\ 2011 & \text { unknown } \\ 2014 & \text { Michael Boyd }\end{array}$

UNIVERSITY OR NON-COMMERCIAL

\begin{tabular}{|c|c|c|}
\hline 2003 & Jeff Dailey (Part II) & $\begin{array}{l}\text { American Theatre of Actors, New } \\
\text { York, USA }\end{array}$ \\
\hline 2013 & unknown & $\begin{array}{l}\text { Marlowe Society, Cambridge } \\
\text { University, UK }\end{array}$ \\
\hline 2015 & Steven Green & Jackson Lane Theatre, London, UK \\
\hline \multicolumn{3}{|c|}{ OPERA PERFORMANCES, STAGED READINGS, AND AUDIO RECORDINGS } \\
\hline 2001 & $\begin{array}{l}\text { Jonathan Miller and } \\
\text { Trevor Pinnock } \\
\text { (Handel) }\end{array}$ & Sadler's Wells Theatre, London, UK \\
\hline 2004 & unknown & $\begin{array}{l}\text { Staged reading, Shakespeare's Globe, } \\
\text { London, UK }\end{array}$ \\
\hline 2005 & Fabio Biondi (Vivaldi) & $\begin{array}{l}\text { Audio recording with DVD, EMI } \\
\text { Records /Virgin Classics }\end{array}$ \\
\hline 2009 & William Lacey (Handel) & $\begin{array}{l}\text { Dorothy Chandler Pavilion, Los } \\
\text { Angeles, CA, USA }\end{array}$ \\
\hline 010 & Graham Vicks (Handel) & Royal Opera House, London, UK \\
\hline
\end{tabular}

Radio broadcast

Radio broadcast, Parts I and II over two days and II

Rose Theatre, London, UK

Bristol Old Vic, Bristol, and Barbicon Theatre, London, UK

Shakespeare Theatre, Washington, D.C., USA

American Shakespeare Center, Staunton, VA, USA

Theatre for a New Audience, Brooklyn, NY, USA
New opera version based on Parts I 
McJannet

\section{References}

Abi-Habib, Maria. 2014. "The Child Soldiers of Syria: Boys Who Escape Islamic State Recount Horrors: 'Like learning to chop an onion.'" Wall Street Journal 264/115: 27-28 December: A1 and A5.

Anon. 1951. "Old Vic: Tamburlaine the Great." Rev. of Tamburlaine, dir. Tyrone Guthrie. The Times (London) 25 September: 8. Times Digital Archive (1785-2009). Farmington Hills, Michigan: Thomson-Gale Publishing, continually updated.

Anon. 1956. "Tamburlaine in Toronto: Canadian Actors for New York." Rev. of Tamburlaine, dir. Tyrone Guthrie. The Times (London) 11 January: 12. Times Digital Archive (1785-2009). Farmington Hills, Michigan: ThomsonGale Publishing, continually updated.

Ashman, Mike. 2010. "Bajazet." Liner notes for Bajazet (Antonio Vivaldi). Cond. Fabio Bondi. Perf. David Daniels, Ildebrando D'Arcangelo, Marijana Mijanovic, Patrizia Ciofi, Vivica Genaux, Elina Garancia. EMI/Virgin Classics. Digital recording with DVD.

Astington, John H. 1993. "The 'Unrecorded Portrait' of Edward Alleyn." Shakespeare Quarterly 44(1): 73-86.

Barbour, David. 2014. "Theatre in Review: Tamburlaine, Parts I and II (Theatre for a New Audience/Polansky Shakespeare Center)." Rev. of Tamburlaine, Parts I and II, dir. Michael Boyd. Lighting and Sound America Online, 12 November. Accessed 5 September 2016.

http://www.lightingandsoundamerica.com/news/story.asp?ID=$\mathrm{US}_{42} \mathrm{CL}$.

Barbour, Richmond. 2003. Before Orientalism: London's Theatre of the East, 1576-1626. Cambridge, Eng.: Cambridge University Press.

Best, Terence. 2002. "The History of Tamerlano." Liner notes to Tamerlano: An Opera in Three Acts (George Frideric Handel). Dir. Jonathan Miller, cond. Trevor Pinnock. The English Concert (PEC Concerts Ltd.). Digital recording with DVD.

Billington, Michael. 1992. "In the Court of a Monster." Rev. of Tamburlaine the Great, dir. Terry Hands. The Guardian, 3 September: 24.

- 1988. "The National Champion: Michael Billington Weighs Up the Achievement of Sir Peter Hall's 15 Years at the National [Theatre]." The Guardian, 31 May: 17. The Guardian (1959-2003). ProQuest Historical Newspapers.

Bourne, Claire M.L. 2015. "Tamburlaine the Great, Parts I and II." Rev. of Tamburlaine, Parts I and II, dir. Michael Boyd. Shakespeare Bulletin 33(2): 347-50.

Brantley, Ben. 2014. "It's Best Not to Make Him Angry." Rev. of Tamburlaine, Parts I and II, dir. Michael Boyd. New York Times, November 18. Accessed 
5 September 2016. http://www.nytimes.com/2014/11/19/theater/ marlowes-tamburlaine-parts-i-and-ii-in-brooklyn.html?_r=o.

Burns, Landon C., ed. 1966. Nicholas Rowe: Tamerlane: A Tragedy (1701). Philadelphia: University of Pennsylvania Press.

Burrows, Donald. 2002. "Handel, Tamerlano, and London." Liner notes to Tamerlano: An Opera in Three Acts (George Frideric Handel). Dir. Jonathan Miller, cond. Trevor Pinnock. The English Concert (PEC Concerts Ltd.). Digital recording.

Christiansen, Rupert. 2010. "Tamerlano at the Royal Opera House." Rev. of Tamerlano (George Frideric Handel), dir. Graham Vick. Daily Telegraph, 8 March: n.p.

Clark, Donald B. 1950. "The Sources and Characterization of Nicholas Rowe's Tamerlane." Modern Language Notes 65(3): 145-52.

Croghan, Lore. 2014. "Tamburlaine Takes the Stage by Storm at the Theatre for a New Audience." Rev. of Tamburlaine, Parts I and II, dir. Michael Boyd. Brooklyn Daily Eagle, 17 November. Accessed 5 September 2016.

http:/ / www.brooklyneagle.com/articles/2014/11/17/tamburlainetakes-stage-storm-theatre-new-audience.

Dawson, Antony, ed. 1997. Christopher Marlowe: Tamburlaine, Parts One and Two (1590). London: A\&C Black and New York: W.W. Norton.

Dodson, Joel 2014. "Review of Tamburlaine, Parts I and II, by Christopher Marlowe, at Theatre for a New Audience, Brooklyn, NY." Dir. Michael Boyd. Marlowe Society Newsletter 34/ 1: 7-8.

Erickson, Peter. 2006. "Afterword: The Blind Side in Colorblind Casting." In Colorblind Shakespeare, edited by Ayanna Thompson, 241-49. New York and London: Routledge.

Fisher, Philip. 2014. "Tamburlaine, Parts I and II." Rev. of Tamburlaine, Parts I and II, dir. Michael Boyd. British Theatre Guide, [November]. Accessed 5 September 2016. http://www.britishtheatreguide.info /reviews/tamburlaine-pa-theatre-for-a-n-11076.

Geckle, George L. 1978. "The National Theatre Production of Tamburlaine." Educational Theatre Journal 30(3): 329-42.

Godwin, Laura G. 2009. "Tamburlaine and Edward II." Rev. of Tamburlaine and Edward II, dir. Michael Kahn and Gale Edwards. Shakespeare Bulletin 27(1): 122-31.

Greenblatt, Stephen. 2005 (1980). "Marlowe and the Will to Absolute Play." In Renaissance Self-Fashioning from More to Shakespeare, rev. ed. with a new Preface, 193-221. Chicago: University of Chicago Press. 
McJannet

Historum. 2012. "Facial Reconstruction of the Timūrids." Accessed 5 September 2016. http://historum.com/asian-history/46604-facialreconstruction-timurids-tamerlane-shah-rukh-ulugh-beg.html.

Hookham, H[ilda] H. 1978. “Timur." Encyclopaedia Britannica: Macropaedia 18: 424-25.

Keenan, Siobhan. 2006. "Christopher Marlowe, Tamburlaine. Presented at the Bristol Old Vic Theatre, October 2005." Rev. of Tamburlaine, dir. David Farr. Early Modern Literary Studies 11(3): 16, para.1-15. Accessed 5 April 2016. https:/ / extra.shu.ac.uk/emls/11-3/revtam.htm.

Knobler, Adam. 2006. "Holy Wars, Empires, and the Portability of the Past." Comparative Studies in Society and History 48(2): 293-325.

- 2001. "Timur the (Terrible/Tartar) Trope: A Case of Repositioning in Popular Literature and History." Medieval Encounters 7(1): 101-12.

Leslie, Nancy T. 1971. "Tamburlaine in the Theatre: Tartar Grand Guignol or Janus?" Renaissance Drama 4: 105-120.

MacPherson, Malcolm. 1976. "King of Carnage." Rev. of Tamburlaine the Great, dir. Peter Hall. Newsweek, 18 October.

Maloon, James. 1977. "From Beast to Mad Beast: A Further Look at Tyrone Guthrie's Tamburlaine." Theatre Survey 18(1): 1-29.

Manz, Beatrice Forbes. 2002. "Tamerlane's Career and its Uses." Journal of World History 13(1): 1-25.

Marlowe Society, Cambridge University. "The History of the Marlowe Society." Accessed 5 September 2016.

http://www.themarlowesociety.com/?page_id+75.

McCauley, Mary Carole. 2010. "The Voice, the Role, the Actor: Avery Brooks, Here for Center Stage's 'Let There Be Love,' Made a Career by Playing Epic Figures." Baltimore Sun, 14 February, n.p. Accessed 5 September 2016. http://articles.baltimoresun.com/2010-02-14/ entertainment/bal-ae.brooks14feb14_1_alfred-center-stage-voice, n.p.

McJannet, Linda. 2006. The Sultan Speaks: Dialogue in English Plays and Histories about the Ottoman Turks. New York: Palgrave Macmillan.

McMahon, Colin. 1999. "The Rehabilitation of Tamerlane." Chicago Tribune, 17 January: n.p. Accessed 5 September 2016. http://articles.chicagotribune.com/1999-01-17/news/990117256_1_uzbek-islam-karimov-tamerlane.htm.

Nightingale, Benedict. 1976. "The Blood and Bombast of Tamburlaine." Rev. of Tamburlaine the Great, dir. Peter Hall, New York Times, 17 October: 73.

O'Brien, Geoffrey. 2014. "Tamburlaine's Seductive Terror." Rev. of Tamburlaine, Parts I and II, dir. Michael Boyd. New York Review of Books Blog, November 24. Accessed 5 September 2016. 
http://www.nybooks.com/blogs/nyrblogs/2014/nov/24/tamburlaines -seductive-terror $/$ ?printpage=true.

Patterson, Richard. 2014. "Tamburlaine, Parts I and II at The Theatre for a New Audience." Rev. of Tamburlaine, Parts I and II, dir. Michael Boyd. Exeunt Magazine. Accessed 5 September 2016.

http:/ / exeuntmagazine.com/reviews/tamburlaine-parts-i-and-ii/.

Potter, Lois. 2009. "What Happened to the Mighty Line? Recent Marlowe Productions." Shakespeare Bulletin 27(1): 63-68.

Said, Edward. 1978. Orientalism. New York: Vintage Books.

Saunders, Charles. 1681. Tamerlane the Great: As it is Acted by Their Majesties' Servants at the Theatre Royal. London: Jacob Tonson.

Shammas, Sam[antha]. 1999. Sam Shammas Productions. "Black is the Beauty of the Brightest Day." Program for Tamburlaine the Great, dir. Sam Shammas. Accessed 30 October 2015. http:/ / www.samshammas.com/tamb.htm.

Shand, Skip. 2006. "Tamburlaine." Rev. of Tamburlaine, dir. David Farr. Shakespeare Bulletin 24(2): 49-54.

Simon, Lizzie. 2014. "John Douglas Thompson Stars in Tamburlaine at Theatre for a New Audience." Rev. of Tamburlaine the Great, dir. Michael Boyd. Wall Street Journal, November 14. Accessed 4 March 2015. http:/ / www.wsj.com/articles/john-douglas-thompson-stars-intamburlaine-at-theatre-for-a-new-audience-1415978702.

Singleton, Brian. 1991. "The Beauty of the Resistible Tyrant: Tamerlan at the Théâtre de l'Épee de Bois." Theatre Research International 16(2): 83-103. Odyssey 144.133.239. Accessed 22 March 2016.

Tagano, Mia. [2015]. Mia Tagano Voiceover. Accessed 28 November 2015. http://www.miatagano.com.

Tasnim. 2012. "Zenocrate and Zabina in Marlowe's Tamburlaine." Muslimah Media Watch, 21 February. Accessed 5 September 2016. http://www.patheos.com/blogs/mmw/2012/o2/zenocrate-andzabina-in-marlowes-tambuirlaine.

Thorp, Willard. 1940. "A Key to Rowe's Tamerlane." Journal of English and Germanic Philology 39(1): 124-27.

Thompson, Ayanna. 2006. "Practicing a Theory/Theorizing a Practice: An Introduction to Shakespearean Colorblind Casting." In Colorblind Shakespeare: New Perspectives on Race and Performance, edited by Ayanna Thompson, 1-24. New York: Routledge.

Violanti, Heather. 2004. "Tamburlaine the Great: Cannon's Mouth Productions 2003." Rev. of Tamburlaine the Great, dir. Ben Naylor. Research Opportunities in Renaissance Drama (RORD) 43: 123-24. 
McJannet

Vitkus, Daniel J. 2001. Turning Turk: English Theatre and the Multicultural Mediterranean. New York: Palgrave Macmillan.

Walker, John. 1976. "An Excellent Opener for the Olivier." Rev. of Tamburlaine the Great, dir. Peter Hall. Herald Tribune, 5 October 1976: n.p. Accessed 5 September 2016.

http://www2.warwick.ac.uk/fac/arts/ren/projects/elizabethan_jacobe an_drama/christopher_marlowe/tamburlaine_stage_history/profession al/1976nt.

Wallace, George M. 2009. "You're Bajazet, Bajazet All the Way." Rev. of Tamerlano (George Frederic Handel), dir. William Lacey. A Fool in the Forest, 29 November. Accessed 5 September 2016.

http:/ / www.afoolintheforest.com/2009/11/tamerlano.html.

Wardle, Irving. 1992. "Marlowe's Rambo Triumphant: Tamburlaine [at the] Swan [Theatre]." Rev. of Tamburlaine the Great, dir. Terry Hands. The Independent, 6 September: n.p. Accessed 15 November 2015.

http:/ / www.independent.co.uk/artsentertainment/theatre--marlowesrambo-triumphant-tamburlaine-swan--merry-wives-of-windsor-royalshakespeare-stratford--amphibians-pit.

How to cite this article:

McJannet, Linda. “Timūr's theatrical journey: Or, when did Tamburlaine become black?" SEDERI 26 (2016): 31-66.

Author's contact: lmcjannet@bentley.edu

Postal address: English and Media Studies, Bentley University - 175 Forest Street -

Waltham, Massachusetts 02452 - United States

Submission: 03/12/2015 Acceptance: 26/02/2016 